\title{
IJIKMMENA
}

$3,3 / 4$

297

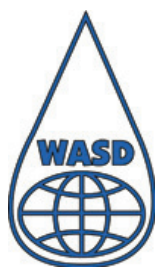

International Journal of Innovation and Knowledge Management in Middle East \& North Africa Vol. 3 No. 3/4, 2014

Copyright (C) 2014 WASD

\section{THE IMPACT OF E-COMMERCE ON GROSS VALUE OF OUTPUT IN IRANIAN MANUFACTURING SMES}

\section{Sarvenaz Hojabr Kiani and Elsadig Musa Ahmed}

Multimedia University, Malaysia ${ }^{1}$

\begin{abstract}
Purpose: This paper determines the impact of e-commerce (EC) on output of Iranian manufacturing SMEs through analyzing and calculating interrelated issues. Design/methodology/approach: The model is based on both econometrics and the growth accounting approach to fill the gaps of previous studies. The first step of this research fills the gap of the growth accounting approach by transforming the model into a parametric model and providing statistical analysis. The second step closes the gap of the econometric estimation of the Cobb-Douglas production function by calculating productivity indicators. This research applies extensive growth theory, which is based on the expansion of the quantity of inputs in order to increase the quantity of output. The model has six EC measurements: the number of employees using a computer; the number of employees using the internet; using the internet to gather information; using the internet to offer information; e-buying; and e-selling, and uses two years panel data.

Findings: The results showed that the impacts of EC on SMEs output using three EC measures-e-selling, using the internet to offer information and the number of employees using the internet-was positive and significant. So SMEs using the internet for selling electronically, using the internet to offer information and the number of employees using the internet have higher GVO (Gross Value of Output) on average, with significant technological progress. SMEs can raise their GVO by using EC.

Originality/value: The findings analyzed in this paper are consistent with underlying modified extensive growth theory.
\end{abstract}

Keywords: E-commerce, SME, GVO, Panel data

${ }^{1}$ Sarvenaz Hojabr Kiani and Elsadig Musa Ahmed, Faculty of Business, Multimedia University, MALAYSIA, Emails: sarvenaz777@gmail.com and elsadigmusa@yahoo.com 


\section{INTRODUCTION}

EC can be a major component in a country's performance and competitiveness, which can lead to economic growth (OECD, 2004). These days convergence between information and businesses offers a new kind of business called electronic commerce (EC) (OECD, 2008). Small and medium enterprises (SMEs) have decisive importance in worldwide economies, including developing countries like Iran. Moreover, job creation in the competitive industrial situation of this new economy is the most important concern for policy makers. As an approved significant job creation source, SMEs could be adopted by any changing circumstance during the building of a competitive renewal environment, and this results from its great flexibilities (Hall and Harvie, 2003; Harvie, 2004).

Due to the regional strategic importance of Iran in the Middle East, adaptation and the use of EC could be beneficial for Iranian SMEs (Central Bank of Iran, 2008). Moreover, increasing the output of SMEs through the adoption of EC can affect many economic factors, such as production, trade, competition and employment. The importance of SMEs in Iran was revealed when an unexpected reduction in the oil price occurred after mid-July 2008. Iran experienced GDP growth, in spite of the fact that its economy was based on oil resources. It is believed that the GDP growth in Iran was the result of the high performance of the non-oil sector. Therefore, the government decided to rely more on private investment and the development of the non-oil sector.

The available financial resources to SMEs, which were provided by the government to support these companies, have been wasted due to ill-matched skills. As a result, SMEs are characterized by low quality of output, since they are input-driven.

This study tries to examine the impact of EC on the output of Iranian manufacturing SMEs and applies extensive growth theory, which is based on the expansion of the quantity of inputs in order to increase the quantity of outputs.

The paper is organized as follows: the next section gives a brief review of the literature. The methodology and models are then explained, followed by a description of data collection and estimation procedures. The results are then presented and discussed, and the last section is devoted to the conclusion of the paper. 
IJIKMMENA $3,3 / 4$
In 2008, OECD released more information about the importance of ICT and EC in both developed and developing countries where it is also acknowledged by other international organizations (IMF, 2003, 2011). The developed countries experience a great contribution of ICT on their economic growth, and some studies show the effectiveness of EC in terms of productivity growth (Liebowitz, 2003; Dedrick et al., 2003). This transforming technology has not produced the same results in developing countries. For example, the Malaysian economy is inputdriven instead of being TFP (total factor productivity) driven, according to Ahmed (2006). Therefore, it is impossible to expect the same results for ICT and EC usage in different countries. The existing literature on developing countries is mostly about the contribution of ICT to different economic factors (e.g. Ahmed, 2006-2008; Pohjola, 2000; Awang, 2004). Moreover, compared to the developed countries, where there is a high level of data availability, the literature on this subject for developing countries, such as Iran $_{\mathbf{d}}$ is restricted by lack of information due to governmental policies. Yet there is no comprehensive study on the impact of EC on economic factors, such as output in these countries, including Iran. This issue reveals the importance of having individual research on each country.

According to Mohamad and Ismail (2009), most of the studies on developing countries are based on upstream issues, which are e-readiness, adoption, and diffusion (e.g. Abbasi, 2007; Ghorishi, 2009; Sanayei et al., 2009) yet there are limited reported studies on the downstream aspect of EC, which has impact. Although there are some studies (e.g., Singh, 2008) based on EC, the lack of concern regarding quantitative approaches is visible. There is thus a gap between empirical and theoretical studies on the downstream issues of EC in developing countries such as Iran.

\section{LITERATURE REVIEW}

The first wave of empirical analysis on the impact of ICT or EC on productivity showed no signs of the computer's impact on increased production. The growth accounting methodology has been used in many studies related to the direct effect of ICT or EC on production.

The growth accounting framework is normally based on a production function wherein it attempts to break down the growth in output into that stemming from changes in inputs and that arising from productivity. 
Based on this approach, the outputs can be obtained, using the services of different inputs. The cost minimizing firm will continue to use its inputs until the marginal cost of each factor equals the marginal product of the factor. Under the growth accounting framework, all incomes are treated as payments to production factors. Given this condition, the growth rate of output is equal to the average weighted growth of production factors, plus the growth which is not taken into account. The ignored growth is the TFP. Therefore, as is mentioned by many researchers, total productivity remains a measure of our ignorance, i.e., part of the growth that is not explicitly taken into account by the firm's costs. This is really the portion that is called Solow's residual (Stiroh, 2002; Van Leeuwen and van der Wiel, 2003; Crepon and Heckel, 2002).

The findings of the researchers show that the use of information and communication technology from the mid-1970s to many years later has been coupled with a decrease in labour and capital productivity in most of the developed countries. This issue led to a well-known claim by the Nobel Prize winner Robert Solow (1957) known as the "productivity paradox": "You can see the computer age everywhere but in the productivity statistics".

Although there was a huge investment in the United States and other countries in the late 1990s, due to the productivity paradox, the productivity benefit of the investment was not significant (Roach, 1988). Economists and IT researchers have different claims and reasons for this phenomenon. According to David (1990), the existence of considerable time lags between the investment and its return is the main cause for the productivity paradox, due to the structural changes in the firm or industry, while Griliches (1994) pointed to measurement problems (especially in the services sector). Oliner and Sichel (1994, 2000) believed that investment in IT compared to total investment has been insignificant, despite increased IT investment. Brynjolfsson and Hitt (2002) blamed the smallness of the sample size due to the shortage of information.

Recently, some analysts claimed that in growth accounting models, computed coefficients of the costs (income) share are smaller than their corresponding coefficients, estimated econometrically. In other words, if the coefficients are estimated (econometrics) instead of computed (growth accounting), ICT capital deepening (more capital per labour) is an essential factor for the growth of labour productivity in econometric models. 
IJIKMMENA $3,3 / 4$

This different result may be related to the ICT spillover effect, which is hidden in the growth accounting approach, while in econometric models, it appears in estimated elasticises. Since ICT goods and services are both the ICT industries' output and inputs of the industries using ICT, ICT can affect economic growth through four channels (Pohjola, 2001):

1. Through the production of ICT services and goods, which directly affect the value added.

2. Increase in the productivity of the ICT production sector, which affects total productivity (TFP).

3. Using ICT capital as an input in producing other goods and services.

4. Production and use of ICT increases productivity in the sectors that do not produce ICT, and hence increases total productivity (spillover effects).

Van Leeuwen and van der Wiel, (2003) tried to justify the difference between results based on the growth accounting and econometrical models by defining and adding the ICT spillover variable as a separate independent variable. According to the researchers, ICT can increase productivity through three well-known mechanisms. First, a fast increase in technical improvement in ICT-related industry can have a considerable share in growth, provided that ICT-related industries expand more rapidly than other sectors. Second, ICT can be a stimulant for the labour force in the production process. Low prices in ICTrelated goods and services can encourage their use, which causes capital deepening, and increases labour productivity. Third, via the spillover effect of technology, ICT can increase productivity. The spillover effect emerges when the social return of the investment is greater than the private return (the case which is suitable for investment in information technology). The researchers then refer to the two empirical growth accounting approaches at industry or macro-level and micro-level studies, mostly using firm-level data, both of which are based on production function. However, empirical evidence on the ICT's share in productivity is different in the two approaches.

Some research indicates that EC has a notable performance, particularly in terms of productivity growth (Dedrick et al., 2003). Bresnahan et al. (2002) found that hardware capital had a significantly 
positive effect on productivity, using panel data from 331 US firms. They reported the positive effects of the ICT capital and skill on value-added.

Criscuolo and Waldron (2003) studied the impact of various measures of EC on productivity in a study titled "e-commerce and productivity". This research was very similar to the work done by Clayton et al. (2004) at firm-level in England. Due to the shortage of information on capital stock in the services sector, it covered only the manufacturing sector. To test the impact of EC on productivity, they regressed the output per labour on the inputs per labour and EC measures. Their selected functional form is Cobb-Douglas. Since they used output rather than its proxy, value-added, which is usually used by researchers, materials input per labour was also added to the regression equation. Although their results showed that e-selling has a negative impact on output growth, e-buying has a positive impact.

The UK study (i.e. Clayton et al., 2004) presents some evidence on pricing effects. Overall, it shows that price transparency, reduced search costs and rapid supplier reaction, which are related to e-marketing and goods sale, probably have a negative impact on prices.

Zwick (2003) studied the impact of the ICT on productivity using value-added as the dependent variable and the Cobb-Douglas production function, and capital, number of employees, a dummy variable for ICT and several other explanatory variables as the control variables. Using cross-sectional data for German firms, Zwick found a positive impact of ICT on productivity.

Clayton et al. (2004) further showed that productivity was not only improved because of selling and buying networks, but also through the way they transformed the internal operations of an enterprise. The findings of Rincon et al. (2005) are very similar to those of Clayton et al. (2004). Rincon et al. (2005) studied the impact of EC at firm level for both service and manufacturing firms. They found that e-buying and e-selling had a positive impact on productivity. Yet the impact of e-selling was more significant for firms in the service sector. Other studies have also focused on EC or the impact of ICT on productivity or output (e.g. Clayton et al., 2004; Atrostic and Nguyen, 2002; Atrostic et al., 2004; Criscuolo and Waldron, 2003; Motohashi, 2001).
The impact of e-commerce on Gross Value of Output in Iranian manufacturing SMEs 302 
IJIKMMENA $3,3 / 4$
In fact, EC is a part of the common transformation process which is created by information and communication technology. EC is part of investment in ICT. Cohen and Kallirroi (2006) concentrated on the basic elements of ICT, and emphasized that they are also applied to EC project evaluation.

Nasab and Aghaei (2009) studied growth model estimation, where ICT investment was an explanatory variable, using panel data for the members of OPEC countries. The outcomes show that ICT has positive and significant effects on the economic growth of those countries who are OPEC members.

Some papers failed to find a significant impact of ICT, such as Loveman (1988), Starssman (1990), Morrison and Berndt (1991), Roach (1987) and Bailey and Gordon (1988). According to Oliner and Sichel (1994), although ICT investment signified a significant share of total fixed business investment, it stands for just a small share of total GDP. On the other hand, there are some difficulties in measuring ICT inputs due to the fast rate of innovation and constantly declining prices, summed up popularly as Moor's Law (the doubling of computing power on semi conductor chips every 12-18 months). Failure to measure ICT inputs or ICT-derived outputs makes it difficult to observe ICT impacts.

Kuppusamy and Shanmugam (2007) conducted a causality study with a co-integration approach on the relationship between economic growth and ICT in Malaysia for the periods 1960-1982 and 1983-2004. Their empirical results indicate that for the period 1960-82, economic growth caused ICT growth, but for the period 1983-2004, the causality was reversed, i.e., ICT caused economic growth in Malaysia.

Seo et al. (2009) employed a different approach and studied the impact of ICT investment on economic growth. Instead of assuming one way causality i.e., the impact of ICT on growth or productivity, which is the usual approach, they used a simultaneous equation to study two way causality, i.e., the interrelationship between economic growth and ICT investment. They applied a sample of 29 countries in the 1990s, and estimated a model using Three Stage Least Square (3LS). One of the most important results of the study is that not only does ICT have an impact on economic growth, but economic growth also has an impact on ICT. 
Using growth accounting methodology, Jalava and Pohjola (2007) have studied the role of electricity and ICT on the economic growth of Finland. Although they refer to the explanation by Hulten (1978) and accept the fact that it is better to use GO (Gross Output) instead of VA (value-added) in the growth accounting approach as the dependent variable, due to lack of data they used VA. Their results indicate that the contribution of ICT to GDP growth is much larger than the contribution of electricity.

The impact of e-commerce on Gross Value of Output in Iranian manufacturing SMEs 304

\section{METHODOLOGY AND MODELS}

The first model in this study is employed to determine the impact of e-commerce on output, which is based on the econometric approach (Brown et al., 1975). The approach employs a method to estimate the output using a Cobb-Douglas production function. The production function positions the maximum quantity of output that could be produced with any given quantities of various inputs. This is a popular definition and can be found in many text books and articles (e.g. Ahuja, 2004 and any micro- and macroeconomic text book). This definition indicates that the inputs should be used efficiently (i.e. the production function shows the output from the efficient use of inputs).

"Many econometrics have studied actual production functions and have used statistical methods to find out relations between changes in physical inputs and physical outputs. A most familiar empirical production function found out by statistical methods is the CobbDouglas production function. Originally Cobb-Douglas production function was applied not to the production process of an individual firm but to the whole of the manufacturing industry. Output in this function was thus manufacturing production" (Ahuja, 2004).

The base for most of the EC (or ICT) models is the Cobb-Douglas function, being consistent with the current literature. The present research also uses the most popular and dominant form of production function, which is the Cobb-Douglas.

According to the designed model, our EC measurements are as follows: the number of employees using the internet, the number of employees using the computer, using the internet to gather information, using the internet to offer information, e-buying, and e-selling activities in industrial sectors of Iranian SMEs. The other variables having impact 
IJIKMMENA in our targeted variables are independent variables (IV). And the $3,3 / 4$ targeted variable output (GVO) is the dependent variable (DV).

\section{ESTIMATION OF CAPITAL STOCK FOR IRANIAN MANUFACTURING SMES}

One of the novelties of this study is to fill the gap of missing data for capital stock in Iranian data-offering organizations like the Central Bank of Iran (CBI) or the Statistical Center of Iran (SCI). Data for stock of capital at firm level is not available for Iran, as is the case in many developing countries. Based on the acceleration theory of investment, the following approach for a rough estimation of a selected sample of 378 Iranian manufacturing SMEs is used ${ }^{2}$. The approach could be used for any extended sample or population of Iranian SMEs, as well as the capital stock estimation at firm-level for other developing countries, or any aggregation level, such as the industrial sector.

Consider the following relation between gross investment and capital stock:

$$
I^{G}=\Delta K_{t}+\lambda K_{t-1}
$$

Where $I^{\mathrm{G}}$ is gross investment, $\Delta K_{t}$ is growth of capital stock (i.e.) which is equal to net investment $I^{N}$, and $\lambda$ is the rate of depreciation.

If for a period of time gross investment $I^{G}$ does not fluctuate much (i.e. the condition of a relatively stable period), one can assume that the capital output ratio is fixed. This is one of the basic assumptions in economic growth theory, which seems to be fairly reasonable in this study, because at least for a short period in the past, the trend of gross investment in Iranian SMEs has been relatively stable. Therefore, this study assumes the capital-output ratio $\frac{K}{Q}$ is constant $\alpha$. Given this assumption, and substituting $\mathrm{K}$ in equation (1), we have:

$$
\begin{aligned}
& I_{+}^{G}=\propto \Delta Q_{+}+\lambda \propto Q_{+-1} \\
& I_{t}^{G}=\propto Q_{t}-\propto Q_{t-1}+\lambda \propto Q_{t-1} \\
& \text { Or: } \\
& I_{t}{ }^{G}=\propto Q_{t}+\propto(\lambda-1) Q_{t-1}
\end{aligned}
$$


If equation (2) is estimated as a multiple regression equation without an intercept, the estimated value of $\alpha$ can be used to calculate the series of $K_{t}$, the capital stock of Iranian SMEs using $K_{t}=\propto Q_{t}$.

To estimate capital stock for our sample of 378 SMEs (i.e. 756 observations for our two years panel) using equation 2, running at least 378 regressions is necessary. In order to save time and space, this study used data for 150 groups of four-digit ISIC codes of our sample covering a time series of gross investment and output for 12 years (i.e. years that the trend of investment was stable), and estimated $\alpha$ coefficients running 150 regressions. Assuming that capital-output ratios $\alpha$, are the same for members of each group of 150 codes, capital stocks were estimated for 756 observations using the relation $K_{t}=\propto Q_{t}(\mathrm{t}=1,2, \ldots, 756)$.

According to the literature, one way to study the impact of EC on output or its growth is to introduce an appropriate measure of EC as an additional explanatory variable to a multiple regression equation of output (Criscuolo and Waldron, 2003; Brnjolfsson and Hitt, 2002; Hempell, 2002a; Maliranta and Rouvinen, 2003; Clayton et al., 2004; Ahmed, 2006-2010; Ahmed and Ridzuan, 2012). Therefore, the appropriate production function would be:

$$
Q=A K^{\alpha_{1}} L^{\alpha_{2}} M^{\alpha_{3}}
$$

The impact of e-commerce on Gross Value of Output in Iranian manufacturing SMEs 306
Where:
Q is Output
A is a constant
$\mathrm{K}$ is physical capital
$\mathrm{L} \quad$ is the number of persons employed (labour)
$\mathrm{M}$ is materials inputs
$\alpha_{1} \quad$ is the output elasticity ${ }^{3}$ of capital
$\alpha_{2}$ is the output elasticity of labour
$\alpha_{3}$ is the output elasticity with respect to materials inputs

Since this study has both numerical and dummy variable measures of EC, the estimation process divides into two steps, as follows:

3 "Output elasticity of a factor shows the percentage change in output as a result of a given percentage change in the quantity of a factor" (Ahuja, 2004; p. 294). 
IJIKMMENA Step 1: Estimation with numerical measures of EC

$3,3 / 4$

To estimate the regression of the Cobb-Douglas production function (3) in linear form, the natural logarithm $(\ln )$ would be taken from both sides of the above equation to obtain:

$$
\mathrm{LnQ}=\ln \mathrm{A}+\alpha_{1} \ln \mathrm{K}+\alpha_{2} \ln \mathrm{L}+\alpha_{3} \ln \mathrm{M}
$$

Now, following Criscuolo and Waldron (2003), Clayton et al. (2004), Brnjolfsson and Hitt (2002), Hempell (2002b), Maliranta and Rouvinen (2003) and others, this study adds an extra variable EC (one of the numerical measures of e-commerce) and the error term $U$. The equation thus becomes:

$$
\ln \mathrm{Q}=\ln \mathrm{A}+\alpha 1 \ln \mathrm{K}+\alpha 2 \ln \mathrm{L}+\alpha 3 \ln \mathrm{M}+\alpha 4 \ln \mathrm{EC}+\mathrm{U}
$$

To complete the model, this research adds human capital, $\mathrm{H}$, to endogonize through the educational technological progress, and uses the subscripts i for cross-sectional units (SMEs) and $t$ for time to obtain the following model:

$$
\begin{gathered}
\operatorname{lnGVO}_{\mathrm{it}}=\ln \mathrm{A}+\alpha_{1} \ln \mathrm{K}_{\mathrm{it}}+\alpha_{2} \ln \mathrm{L}_{\mathrm{it}}+\alpha_{3} \ln \mathrm{M}_{\mathrm{it}}+\alpha_{4} \ln \mathrm{H}_{\mathrm{it}}+\alpha_{5} \ln E C_{\mathrm{it}}+\mathrm{U}_{\mathrm{it}}(6) \\
\mathrm{i}=1,2 \ldots 378 \\
\mathrm{t}=1,2
\end{gathered}
$$

Where:

$\begin{array}{ll}\text { GVO } & \text { is Gross Value of Output } \\ \text { A } & \text { is constant (average TFP) } \\ \mathrm{K} & \text { is capital input } \\ \mathrm{L} & \text { is number of persons employed (labour) } \\ \mathrm{M} & \text { is materials inputs } \\ \mathrm{H} & \text { is human capital (skilled and unskilled } \\ & \text { employees) } \\ \mathrm{EC} & \text { is numerical measure of EC (number of } \\ & \text { employees using internet, } \\ & \text { number of employees using computer) } \\ \alpha 1, \alpha 2, \alpha 3, \alpha 4, \alpha 5 & \begin{array}{l}\text { are elasticities } \\ \mathrm{Ln}\end{array} \\ \mathrm{U} & \text { is natural logarithm } \\ & \text { is error term (i.e. disturbance) }\end{array}$




\section{Step 2: Estimation with dummy variable measures of EC}

In this case, since the EC measure is a dummy variable and takes values of either 1 or 0 , it is impossible to use $\ln$ for linear transformation of the Cobb-Douglas production function. Therefore, this study proposes the following version of the inclusion of $\mathrm{EC}$ in this function as:

$$
Q=A K^{\alpha_{1}} L^{\alpha_{2}} M^{\alpha_{3}} H^{\alpha_{4}} e^{\alpha_{5} E C}
$$

Taking natural logarithm $(\mathrm{ln})$ from both sides of the above equation, using subscripts $i$ for cross-sectional units (SMEs) and $t$ for time, and adding the error term $U$, equation (7) becomes:

$$
\begin{gathered}
\operatorname{lnGVO}_{\text {it }}=\ln A+\alpha_{1} \ln K_{\text {it }}+\alpha_{2} \ln L_{i t}+\alpha_{3} \operatorname{lnM}_{\text {it }}+\alpha_{4} \ln H_{\text {it }}+\alpha_{5} \mathrm{EC}_{\text {it }}+U_{\text {it }} \\
\text { i }=1,2 \ldots 378 \\
t=1,2
\end{gathered}
$$

It is obvious that $\ln \mathrm{e}=1$ and $\mathrm{e} \approx 2.7182$. In the above equation, when the logarithm takes from $e^{\alpha_{5} E C}$ then $e^{\alpha_{5} E C}=\alpha_{5} E C l n e=\alpha_{5} E C \ln =$

\section{Where:}

$\begin{array}{ll}\text { GVO } & \text { is Gross Value of Output } \\ \text { A } & \text { is constant (average TFP) } \\ \text { K } & \text { is capital input } \\ \text { L } & \text { is number of persons employed (labour) } \\ \mathrm{M} & \text { is materials inputs } \\ \mathrm{H} & \text { is human capital (skilled and unskilled employees) } \\ \mathrm{EC} & \text { takes value } 1 \text { for the firms using the internet to gather } \\ & \text { information } \\ & \text { takes value } 0 \text { for the firms not using the internet to } \\ & \text { gather information } \\ & \text { takes value } 1 \text { for the firms using the internet to offer } \\ & \text { information } \\ & \text { takes value } 0 \text { for the firms not using the internet to } \\ & \text { offer information } \\ & \text { takes value } 1 \text { for firms with e-buying } \\ & \text { takes value } 0 \text { for firms without e-buying } \\ & \text { takes value } 1 \text { for firms with e-selling } \\ & \text { takes value } 1 \text { for firms without e-selling } \\ & \text { are elasticities } \\ & \text { is coefficient of dummy variable }\end{array}$

The impact of e-commerce on Gross Value of Output in Iranian manufacturing SMEs 308 


$\begin{array}{lll}\text { IJIKMMENA } & \text { Ln } & \text { is natural logarithm } \\ 3,3 / 4 & \mathrm{U} & \text { is error term (i.e. disturbance) } \\ & \mathrm{e} & \text { is base for natural log }\end{array}$

\section{DATA COLLECTION AND ESTIMATION PROCEDURE}

The data used in this study are secondary data developed by SCI based on a survey conducted by this department for the period of 2006 and $2007^{4}$. In this study, the population is Iranian SMEs among manufacturing industry firms. Following the definition of SCI, firms with 10-100 employees are the target SMEs of this research. Since the questionnaires have been distributed by SCI of Iran among approximately 12,000 firms and the raw data is available for two years to select the sample, this study uses the appropriate sampling method. These data consist of Gross Value of Output and total number of employed persons as well as the number of skilled and unskilled labour, which is considered to be a good measure of human capital, since most of the workers are family owners who do not receive regular salaries. These data also include total number of SMEs, EC facilities, wages and salaries.

Although a panel of two years is a short panel, the following studies justify this usage: Atrostic and Nguyen $(2002,2005)$ (2 years panel), Maliranta and Rouvinen (2003) (3 years panel), Maliranta and Rouvinen (2006) (2 years panel), Criscuolo and Waldron (2003) (2 years panel), Farooqui (2005) (4 years panel), Gujarati and Porter (2009) (2 years panel), Wooldridge $(2002,2006)$ (2 years panel).

This study uses a probability sampling method, namely, Stratified Sampling (Mann, 1998). Moreover, one type of panel model has constant coefficients, referring to both intercepts and slopes. If, in this study, there are neither significant SME effects nor time effects, all the data can be pooled, whereupon an Ordinary Least Squares (OLS) regression model could be run. This model is called pooled regression or a common effect model. Another type of panel model would have constant slopes but intercepts that differ according to the crosssectional (group) unit, for example, the SMEs. While the intercept in cross-section (group) is specific, for example, it differs here from SME to SME in that it may or may not change over time. These models are called Fixed Effects Models (FEM), due to fixed rather than random

\footnotetext{
${ }^{4}$ Note that only this two year data for EC measures is available from SCI.
} 
differences. There exists another type of fixed effect model which could have constant slopes, but the intercepts vary over time. In this case, the model would have no significant SME differences, but might have different time effects. There is another fixed effect panel model where the slope coefficients are constant, but the intercept varies over $\mathrm{SME}$ as well as time. Another type of fixed effect model has differential intercepts and slopes. This kind of model has intercepts and slopes that both vary according to the SME. There is also a fixed effects panel model in which both intercepts and slopes might vary according to SME and time. All of the fixed effects models can be formulated using dummy variables, and are called Least Squares Dummy Variable (LSDV) models. To avoid falling into the dummy variable trap, the number of dummy variables should be one less than the number of cross-sectional units, i.e., n-1 (Gujarati, 2003).

The first step in estimating panel data models is to choose between pooled and fixed effects models. To do so, the restricted $\mathrm{F}$ (i.e. Leamer $\mathrm{F}$ statistics) test is used (Gujarati, 2003, Gujarati and Porter, 2009; Baltagi, 2008; Greene, 2003).

$$
F=\frac{R R S S-U R S S /{ }_{N-1}}{U S S R /{ }_{N T-N-K}}
$$

"This is a simple Chow test with the restricted residual sum of squares (RRSS) being that of OLS on the pooled model and the unrestricted residual sum of squares (URSS) being that of the LSDV regression" (Baltagi, 2005, p. 13). In (9), $N$ is the number of cross-sectional units, $T$ is the number of times and $K$ is the number of independent variables.

One problem with the LSDV approach arises when there are too many cross-sectional units, which in this case is due to the large number of SMEs. This model has too many dummy variables, which produce multicollinearity, and also the degree of freedom of the model is reduced significantly. To overcome this problem, one can eliminate dummy variables by differencing sample observations around their sample means. This approach produces what is called "within-group estimators" (Gujarati and Porter, 2009; Baltagi, 2005, 2008; Greene, 2003). Another approach is to use the first difference of variables in both sides of the regression equation. This is called the first difference method. Since here there is a short panel with only two time periods, it is very important to state the following: 
IJIKMMENA $3,3 / 4$

"It may be pointed out that the first difference and fixed effects estimators are the same when we have only two time periods, but if there are more than two periods, these estimators differ" (Gujarati and Porter, 2009, p. 602). To support the above statement, Gujarati and Porter (2009) claimed that "the reasons for this are rather involved" and referred to Wooldridge (2002). There is another model called the random effect model (REM). Here, the difference in intercepts ${ }^{5}$ (or slopes) is random rather than fixed.

As mentioned before, the first step in panel data regression analysis is to choose between the pooled regression model and FEM using the Leamer F statistic. If one chooses FEM, the second step is to select between FEM and REM. The Hausman test, which is very popular and is explained in detail in many econometrics text books including Greene (2003), Davidson and Mackinnon (2004) and Baltagi (2005, 2008), could be used to choose between FEM and REM. To use a time series for prediction, the assumption of stationary for variables is required. A variable is stationary if its mean, variance and covariance do not change over time, i.e. the main characteristics are stable. If variables of the time series model are non-stationary i.e. they have unit-root, then the usual $\mathrm{t}, \mathrm{F}$ and R2 are not valid. In this case, the probability of having spurious (non-sense) regression is high, i.e., we may conclude there is a relation between unrelated variables. But there are some cases where there are valid regression results among non-stationary variables. In this case it is said that the variables are co-integrated (Gujarati and Porter, 2009; Enders, 2010).

Unit-root and co-integration tests have become very popular, but tests for them are for time series rather than for cross-sectional series. For a short panel like the one in the present study, with only two time dimensions, unit-root and co-integration tests are not required (Baltagi, 2005, p. 237 and p. 247). Moreover, for large $\mathrm{N}$ and very small T (i.e. large cross-section and very small time, as in this study), the usual panel procedure ignoring unit-root and co-integration is recommended (Gujarati and Porter, 2009; Enders, 2010).

${ }^{5}$ In panel data regression analysis, assuming different intercepts is much more popular than assuming different slopes. Concerning this research, due to the lack of data, there are a limited number of studies in the literature that have used panel data approaches (i.e. FEM or REM). However all of these models are constructed to have different intercepts. 


\section{RESULTS AND DISCUSSION}

According to the results of estimation, among the measures of EC, the two best, most accurate and reliable measures, namely, e-selling and using the internet to offer information, have positive impacts on Gross Value of Output (GVO), indicated by highly significant coefficients of EC in Tables 3 and 5 of the appendix, respectively.

Table 3 shows that the coefficient of EC (measured by e-selling) is positive, which indicates that those Iranian manufacturing SMEs who use the internet for selling electronically have a higher average output. The rate of growth of GVO due to e-selling is equal to 0.478 per cent $\left(e^{0.391}-1=1.478-1=0.478\right)$. Therefore, Iranian SMEs with e-selling could raise their GVO by 0.478 per cent.

Table 5 shows that the coefficient of EC (measured as using the internet to offer information) is positive, which indicates that Iranian manufacturing SMEs using the internet to offer information have a higher average output. The rate of growth of GVO due to use of the internet to offer information is equal to 0.191 per cent $\left(e^{0.175}-1=1.191-1=0.191\right)$. Therefore, Iranian manufacturing SMEs using the internet to offer information could raise their GVO by 0.191 per cent. Notice that the impact of e-selling is much higher than using the internet to offer information. This finding seems reasonable because offering information may not lead to higher selling (whereas e-selling can raise selling directly), which could directly raise GVO.

Table 1 shows the coefficient of EC (measured by the number of employees using the internet) is highly significant (i.e. significant at the 5 per cent level). This is an indication of EC impact, as a one per cent increase in the number of employees using the internet increases GVO (output) by 0.014 per cent.

On the other hand, three other measures of EC, namely, e-buying, using the internet to gather information and the number of employees using the computer did not have any significant impacts on GVO (Tables 4, 6 and 2).

The coefficients of inputs, materials, labour, capital and human capital are all significant in all of the regression equations of the model using different measures of EC. These results indicate that all of the inputs of production have positive impacts on output (GVO).
The impact of e-commerce on Gross Value of Output in Iranian manufacturing SMEs

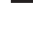


APPENDIX

\section{$3,3 / 4$}

$\begin{gathered}\text { Independent } \\ \text { variable }\end{gathered}$
Random Effects-Estimated Generalized Least Squares
( EGLS)
variable

( EGLS)

\begin{tabular}{|c|c|c|c|c|c|}
\hline \multirow[b]{2}{*}{313} & \multirow[b]{2}{*}{ Constant } & Coefficient & Standard error & $\mathrm{t}$-Statistics & $P$ \\
\hline & & 7.217 & 0.832 & 8.672 & 0.000 \\
\hline & $\ln \mathrm{L}$ & 0.344 & 0.107 & 3.202 & 0.001 \\
\hline & $\ln K$ & 0.511 & 0.018 & 28.105 & 0.000 \\
\hline & $\ln M$ & 0.152 & 0.042 & 3.619 & 0.000 \\
\hline & $\ln \mathrm{H}$ & 0.061 & 0.037 & 1.652 & 0.099 \\
\hline & $\operatorname{lnEC}$ & 0.014 & 0.007 & 1.918 & 0.055 \\
\hline Estimation results & Leamer F & 5.457 & & & 0.000 \\
\hline of the impact of & Hasuman & 70.456 & & & 0.000 \\
\hline EC (number of & chi-squared & & & & \\
\hline
\end{tabular}

internet) on GVO

Source: Estimated by using equation No. 6

Independent Random Effects-Estimated Generalized Least Squares variable

( EGLS)

\begin{tabular}{lcccc} 
& Coefficient & Standard error & t-Statistics & $P$ \\
\hline Constant & 7.019 & 0.835 & 8.408 & 0.000 \\
$\operatorname{lnL}$ & 0.365 & 0.108 & 3.367 & 0.001 \\
$\operatorname{lnK}$ & 0.510 & 0.018 & 27.968 & 0.000 \\
$\operatorname{lnM}$ & 0.154 & 0.042 & 3.657 & 0.000 \\
$\ln \mathrm{H}$ & 0.062 & 0.037 & 1.675 & 0.094 \\
$\operatorname{lnEC}$ & 0.008 & 0.011 & 0.716 & 0.475 \\
Leamer F & 5.524 & & & 0.000 \\
Hasuman & 67.606 & & & 0.000 \\
chi-squared & & & & \\
\hline
\end{tabular}

Table 2. Estimation results of the impact of EC (Number of employees using computer) on GVO 
Independent variable

Fixed Effects-Estimated Generalized Least Squares ( EGLS)

\begin{tabular}{lcccc} 
& Coefficient & Standard error & t-Statistics & $P$ \\
\hline Constant & 8.061 & 0.058 & 139.036 & 0.000 \\
$\ln \mathrm{L}$ & 0.391 & 0.005 & 7.793 & 0.000 \\
$\ln \mathrm{P}$ & 0.368 & 0.0003 & 1296.773 & 0.000 \\
$\ln \mathrm{M}$ & 0.220 & 0.003 & 77.730 & 0.000 \\
$\ln \mathrm{H}$ & 0.082 & 0.004 & 20.713 & 0.000 \\
EC & 0.391 & 0.029 & 13.580 & 0.000 \\
Leamer F & 5.546 & & & 0.000 \\
Hasuman chi- & 65.443 & & & 0.000 \\
squared & & & & \\
\hline
\end{tabular}

Source: Estimated by using equation No. 8
The impact of e-commerce on Gross Value of Output in Iranian manufacturing SMEs 314

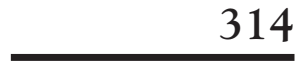

Table 3. Estimation results of the impact of EC (e-selling) on GVO

Independent Random Effects-Estimated Generalized Least Squares variable

( EGLS)

\begin{tabular}{lcccc} 
& Coefficient & Standard error & t-Statistics & $P$ \\
\hline Constant & 6.827 & 0.818 & 8.345 & 0.000 \\
$\ln \mathrm{L}$ & 0.388 & 0.106 & 3.646 & 0.000 \\
$\operatorname{lnK}$ & 0.510 & 0.018 & 28.011 & 0.000 \\
$\ln \mathrm{M}$ & 0.160 & 0.042 & 3.815 & 0.000 \\
$\ln \mathrm{H}$ & 0.070 & 0.037 & 1.910 & 0.056 \\
EC & -0.182 & 0.147 & -1.237 & 0.22 \\
Leamer F & 5.541 & & & 0.000 \\
Hasuman & 67.711 & & & 0.000 \\
chi-squared & & & &
\end{tabular}

Table 4. Estimation results of the impact of EC Source: Estimated by using equation No. 8 (E-buying) on GVO 


\begin{tabular}{|c|c|c|c|c|c|}
\hline & & & & & \\
\hline $\begin{array}{l}\text { IJIKMMENA } \\
3,3 / 4\end{array}$ & $\begin{array}{l}\text { Independent } \\
\text { variable }\end{array}$ & Fixed Eff & $\begin{array}{l}\text { Estimated Gener } \\
\text { ( EGLS) }\end{array}$ & ed Least Squ & \\
\hline & & Coefficient & Standard error & $\mathrm{t}$-Statistics & $P$ \\
\hline & Constant & 8.256 & 0.087 & 95.310 & 0.000 \\
\hline & $\ln \mathrm{L}$ & 0.352 & 0.005 & 72.499 & 0.000 \\
\hline & $\ln K$ & 0.376 & 0.004 & 94.831 & 0.000 \\
\hline & $\ln M$ & 0.210 & 0.003 & 71.586 & 0.000 \\
\hline & $\ln \mathrm{H}$ & 0.087 & 0.005 & 15.903 & 0.000 \\
\hline & $\mathrm{EC}$ & 0.175 & 0.004 & 39.439 & 0.000 \\
\hline $\begin{array}{l}\text { Table } 5 \text {. Estimation } \\
\text { results of the }\end{array}$ & Leamer F & 5.455 & & & 0.000 \\
\hline impact of EC (Using & Hasuman chi- & 67.294 & & & 0.000 \\
\hline the internet to & squared & & & & \\
\hline on GVO & & $\sin$ & & & \\
\hline
\end{tabular}
$\begin{aligned} & \text { Independent } \\ & \text { variable }\end{aligned} \quad$ Random Effects-Estimated Generalized Least Squares
( EGLS)

\begin{tabular}{lcccc} 
& Coefficient & Standard error & t-Statistics & $P$ \\
\hline Constant & 7.024 & 0.822 & 8.543 & 0.000 \\
$\ln \mathrm{L}$ & 0.360 & 0.107 & 3.355 & 0.000 \\
$\ln \mathrm{C}$ & 0.510 & 0.018 & 28.063 & 0.000 \\
$\ln \mathrm{M}$ & 0.152 & 0.042 & 3.608 & 0.000 \\
$\ln \mathrm{H}$ & 0.063 & 0.037 & 1.713 & 0.087 \\
EC & 0.122 & 0.100 & 1.215 & 0.225 \\
Leamer F & 5.485 & & & 0.000 \\
Hasuman chi- & 71.521 & & & 0.000 \\
squared & & & & \\
\hline
\end{tabular}

Source: Estimated by using equation No. 8 


\section{CONCLUSION}

As developing countries like Iran have mostly used capital and labour without proper adaptation of new technology over the past few years, limited skilled labour might be a source of restriction on the utilization of capital. There is a need for skilled labour to carry out the new technologies (such as EC) with the intention that available capital stock can be used efficiently. GVO of the Iranian manufacturing SMEs in this study showed significant increase in the usage of some of the EC measurements where there was no effect on the others. This can be attributed to the quality of labour involved in these manufacturing SMEs. There are unskilled labourers and family owners in these enterprises who still follow traditional methods in some of their production and other systems, which is why the effect did not show up in some cases.

GVO may depend on physical capital or new technology (which can be the skill of workers) or even on human capital and the quantity and quality of workers cooperation. In an environment where most of the labourers are unskilled, controlling this situation is difficult. This condition may cause no effects to be observed in some situations. The fact that e-buying, using the internet to gather information and number of employees using the computer did not show any significant impact on GVO may be justified by the following reasoning: First, improper usage of the computer, inadequate method of electronic purchasing or improper internet usage to gather information by Iranian manufacturing SMEs. Second, the well-know claim by Nobel Prize winner Robert Solow (1956, 1957, 1987), known as the productivity paradox: "you can see the computer age everywhere but in the productivity statistics". Therefore, computer usage may not increase Iranian manufacturing SMEs GVO through productivity increase. Third, in the case of computer usage or the internet for e-buying or to gather information, technology may not be effective on productivity or GVO through productivity because it is input-driven rather than productivity driven. According to Elsadig Musa Ahmed (2008), economic growth in many countries has been input-driven rather than technology driven.

According to the results of the study, among the measures of EC, the two best, most accurate and reliable measures, namely, e-selling 
IJIKMMENA $3,3 / 4$ and use of the internet to offer information have a positive impact on GVO, as indicated by highly significant coefficients of EC. The coefficient of EC (measured by e-selling) is positive, which indicates that Iranian manufacturing SMEs that use the internet for electronic selling have higher GVO on average. The coefficient of EC (measured as use of the internet to offer information) is positive, which indicates that Iranian manufacturing SMEs that use the internet to offer information have higher GVO on average. Moreover, the coefficient of EC (measured by the number of employees using the internet) is highly significant. All of the input coefficients, namely: $\mathrm{L}, \mathrm{K}, \mathrm{H}$, are significant, which indicates that using physical inputs will definitely increase the output of SMEs.

\section{REFERENCES}

Abbasi, A. (2007), "Information Technology Policy Program", College of Engineering, Seoul National University, Seoul, Korea.

Ahmed, E.M. (2006), "The Effects of Human Capital on Malaysia's Manufacturing Productivity Growth", International Business $\mathcal{B}$ Economics Research Journal, Vol. 5 No. 49.

Ahmed, E.M. (2008), "ICT and Human Capital Intensities impact on ASEAN5 Productivity", The Journal of Knowledge Economy $\mathbb{E}$ Knowledge Management, Vol. IV, Spring.

Ahmed, E.M. (2008), "Foreign Direct Investment Intensity Effects on TFP Intensity of ASEAN 5 plus 2", Journal of Economic Development, Vol. 33 No. 2, pp. 155-166.

Ahmed, E.M. (2009), "Capital Productivity Determinants: East Asian Perspectives", International Journal of Sustainable Economy, Vol. 1 No. 3, pp. 245-254.

Ahmed, E.M. (2010), "Human capital and ICT per Capital Contribution East Asian Productivity Growth”, International Social Science Review, Vol. 85 Nos. $1 \& 2$.

Ahmed, E.M. and Ridzuan, R. (2012), "The impact of ICT on East Asian Economic Growth: Panel Estimation Approach", Journal of the Knowledge Economy, DOI 10.1007/s1313-012-0096-5.

Ahuja, H.L. (2004), Principles of Microeconomics, A New Look at Economic Theory, S Chand and Company Ltd., Ram Nagar, New Delhi. 
Atrostic, B.K. and Nguyen, S.V. (2002), Computer Networks and US Manufacturing Plant Productivity: New Evidence from the CNUS Data, Center for Economic Studies, US Census Bureau, Washington, DC.

Atrostic, B.K. and Nguyen, S. (2005), "Computer Investment, Computer Networks and productivity", Working Papers 05-01, Center for Economic Studies, US Census Bureau.

Atrostic, B.K. and Nguyen, S. (2004), "IT and Productivity in US The impact of e-commerce on Gross Value of Output in Iranian manufacturing SMEs Manufacturing: Do Computer Networks Matter?" Economic Inquiry, Oxford University Press, Vol. 43 No. 3, pp. 493-506.

Awang, H. (2004), "Human Capital and Technology Development in Malaysia", International Education Journal, Vol. 5 No. 2, pp. 239-246.

Baily, M.N. and Gordon, R.J. (1988), "The Productivity Slowdown, Measurement Issues, and the Explosion of Computer Power", Brookings Papers on Economic Activity, Vol. 19 Issue 2, pp. 347-432.

Baltagi, B. H. (2005), Econometric Analysis of Panel Data, $3^{\text {rd }}$ edition, John Wiley \& Sons Ltd, Chichester, UK.

Baltagi, B.H. (2008), Econometric Analysis of Panel Data, $4^{\text {th }}$ Edition, John Wiley \& Sons Ltd, Chichester, UK.

Baltagi, B.H. (2011), Econometrics, $5^{\text {th }}$ edition, Spring Heidelberg Dordercht, London, New York, pp. 81-84.

Bresnahan, T.F., Brynjolfsson, E. and Hitt, L.M. (2002), "Information Technology, Workplace Organization, and the Demand for Skilled Labor: Firm-level Evidence", Quarterly Journal of Economics, Vol. 117 No. 1, pp. 339-376.

Brown, R.L., Durbin, J. and Evans, J.M. (1975), "Techniques for Testing the Constancy of Regression Relationships over time", Journal of the Royal Statistical Society (Series B), No. 37, pp. 149-192.

Brynjolfsson, E. and Hitt, L.M. (2002), "Computing Productivity: FirmLevel Evidence”, Mit Sloan Working Paper, 19 Nov, No. 4210-01.

Central Bank of Iran (CBI), Annual Report 2008.

Clayton, T. Criscuolo, P., Goodridge C. and Waldron, K. (2004), "Enterprise e-commerce: Measurement and Impact", The Economic Impact of ICT - Measurement, Evidence and Implications, OECD, Paris, pp. 241-260. 
IJIKMMENA Cohen, S. and Kallirroi, G. (2006), "E-commerce investment from $3,3 / 4$ an SME perspective: Costs, Benefits and Processes", The Electronic Journal Information Systems Evaluation, Vol. 9, Issue 2, pp. 45-56.

Crepon, B. and Heckel, T. (2002), "Computerization in France: An Evaluation Based on Individual Company Data", Review of Income and Wealth, Vol. 48, pp. 77-98.

Criscuolo, C. and Waldron, K. (2003), E-commerce and Productivity, Economic Trends, Vol. 600.

David, P.A. (1990), "The Dynamo and the Computer: An Historical Perspective on the Modern Productivity Paradox", American Economic Review, Vol. 80 No. 2, May, pp. 355-361.

Davidson, R. and MacKinnon, J.G. (2004), Econometric Theory and Methods, New York: Oxford University Press.

Dedrick, J., Gubaxani, V. and Kraemer, K.L. (2003), Information Technology and Economic Performance: A Critical Review and Empirical Evidence, ACM Computing surveys, University of California at Irvine.

Enders, W. (2010), Applied Econometric Times Series, $3^{\text {rd }}$ ed., ISBN 9780-470-50539-7.

Farooqui. S. (2005), "Information and Communication Technology use and productivity. Office for National Statistics", Economic Trends, Vol. 625, December.

Ghorishi, M. (2009), "E-commerce adoption model in Iranian SME's: investigating the causal link between perceived strategic value of e-commerce \& factor of adoption”, Masters thesis, Luleå University of Technology, dept. of Business Administration and Social Sciences.

Greene, W.H. (2003), Limited Version 8 Econometric Modeling Guide, Vol. 1. Plainview, NY: Econometric Software, pp. E8_1-E8_98; E8_26-E8_30.

Griliches, Z. (1994), "Productivity, R\&D, and the Data Constraint", American Economic Review, Vol. 84 No. 1, pp. 1-23.

Gujarati, D. (2003), Basic Econometrics, $4^{\text {th }}$ ed, New York: McGraw Hill.

Gujarati, D.N. and Porter, D.C. (2009), Basic Econometrics, 5 ${ }^{\text {th }}$ ed, McGraw Hill Companies, Inc. 
Hall, C. and Harvie. C. (2003), A comparison of the performance of SMEs in Korea and Taiwan: Policy implications for turbulent times, University of Wollongong, Faculty of Commerce, Economics Working Paper Series.

Harvie, C. (2004), East Asian SME Capacity Building, Competitiveness and Market Opportunities in a Global Economy, University of Wollongong, Economics Working Paper Series, August, available from http://www.uow.edu.au

The impact of e-commerce on Gross Value of Output in Iranian manufacturing SMEs 320

Hempell, T. (2002a), Does Experience Matter? Productivity Effects of ICT in the German Service Sector, Center for European Economic Research: Mannheim, Discussion Paper 02-43.

Hempell, T. (2002b), What's Spurious, What's real? Measuring the Productivity Impact of ICT at the Firm-Level, ZEW Discussion Paper, 02-42, Mannheim.

Hulten, C.R. (1978), "Growth Accounting with Intermediate Inputs", Review of Economic Studies, Vol. 45, pp. 511-518.

IMF. (2003), Information Technology and Productivity Growth, IMF Working Paper, International Monetary Fund, WP/03/15.

IMF. (2011), ICT, Financial Inclusion, and Growth: Evidence from African Countries, IMF Working Paper, International Monetary Fund, WP/11/73.

Jalava, J. and Pohjola, M. (2007), "The roles of electricity and ICT in economic growth: Case Finland", Science Direct. Explorations in Economic History, Vol. 45 Issue 2, pp. 231-234.

Kuppusamy, M. and Shanmugam, B. (2007), "Islamic Countries economic growth and ICT Development: The Malaysian Case", Journal of Economic Cooperation, Vol. 28 No. 1, pp. 99-114.

Liebowitz, S. (2003), Rethinking the Network Economy: The True Forces Driving the Digital market Place, New York, American Press.

Loveman, G.W. (1988), An Assessment of Productivity Impact on Information Technologies. MIT Management in the 1990s, Working Paper, No. 88-054.

Maliranta, M. and Rouvinen, P. (2003), Productivity Effects of ICT in Finish Business, The Research Institute of the Finnish Economy, Discussion Papers, No. 852. 
IJIKMMENA

$3,3 / 4$
Maliranta, M. and Rouvinen, P. (2006), "Information Mobility and Productivity: Finnish evidence", Economics of Innovation and New Technology, Vol. 15 No. 6, pp. 605-616.

Mann, P.S. (1998), Introductory Statistics, $3^{\text {rd }}$ ed., John Wiley and Sons, INC.

Mohamad, R. and Ismail, N.A. (2009), Electronic Commerce Adoption in SME: The Trend of Prior Studies, Journal of Internet Banking $\mathcal{E}$ Commerce; Vol. 14, Issue 2.

Morrison, C.J. and Berndt, E.R. (1991), Assessing the Productivity of Information Technology Equipment in US Manufacturing Industries, National Bureau of Economic Research, Working Paper No. 3582, (January).

Motohashi, K. (2001), Economic Analysis of Information Network Use: Organizational and Productivity Impacts on Japanese Firms, Research and Statistics Department, METI, Mimeo.

Nasab, E.H. and Aghaei, M. (2009), "The Effect of ICT on Economic Growth: Further Evidence", International Bulletin of Business Administration, ISSN: 1451-243X Issue 5.

OECD. (2004, 2008), Information Technology Outlook.

Oliner, S.D. and Sichel, D.E. (1994), "Computers and Output Growth Revisited: How Big is the Puzzle?" Brookings Papers on Economic Activity 2, pp. 273-333.

Oliner, S.D. and Sichel, D.E. (1994), "Computers and Output Growth Revisited: How Big is the Puzzle?" Brookings Papers on Economic Activity 2, pp. 273-333.

Oliner, S.D. and Sichel, D.E. (2000), The Resurgence of Growth in the late 1990s: Is Information Technology the Story? Federal Reserve Board, Washington, DC.

Pohjola, M. (2000), Information Technology and Economic Growth: A Cross Country Analysis, UNU/WIDER. Working Paper 173.

Pohjola, M. (2001), Information Technology, Productivity, and Economic Growth: International Evidence and Implications for Economic Development, OUP Catalogue, Oxford University Press, Number 9780199243983, December.

Rincon, A. Robinson, C. and Vecchi, M. (2005), The productivity impact of e-commerce in The UK, 2001, The National Institute of Economic and Social Research. 
Roach, S. (1987), American's Technology Dilemma: A Profile of the Information Economy, New York: Morgan Stanley.

Roach, S. (1988), White-collar Productivity: A Glimmer of Hope? New York: Morgan Stanley.

Sanayei, A., Torkestani, M.S. and Ahadi, P. (2009), "Readiness Assessment of Iran's Insurance Industry for E-commerce and E-insurance Success", International Journal of Information Science and The impact of e-commerce on Gross Value of Output in Iranian manufacturing SMEs Management, Vol. 7 No. 1.

Seo, H-J., Lee, Y.S. and Oh, J.H. (2009), "Does ICT investment widen the growth gap?" Telecommunications Policy, Vol. 33, Issue 8, pp. 220 278.

Singh, S. (2008), "Impact of e-commerce on economic models: Little to lose; more to gain”, International Journal of Trade and Global Markets, Vol. 1 No. 3, pp. 319-337.

Solow, R.M. (1956), "Technological change and the aggregate production function", Review of Economics and Statistics Journal, Vol. 39 No. 3, pp. 312-320.

Solow, R.M. (1957), "Technical change and the aggregate production function", Review of Economics and Statistics, Vol. 39, pp. 312-320.

Solow, R.M. (1987), "We'd Better Watch Out”, New York Times Book Review.

Stiroh, K. (2002), "Information technology and the US productivity revival: a review of the evidence”, Business Economics, pp. 30-37.

Strassmann, P.A. (1990), "The Business Value of Computers”, Information Economics Press, New Canaan, Conn.

Van Leeuwen, G. and van der Wiel, H. (2003), "ICT, Innovation and Productivity", CAED Conference, London.

Wooldridge, J.M. (2002), "Econometric Analysis of Cross Section and Panel Data”, MIT Press.

Wooldridge, J.M. (2006), Introductory Econometrics: A Modern Approach, $3^{\text {rd }}$ ed., Thomson South-Western Publishing, Chapter 7, pp. 230-270.

Zwick, T. (2003), The Impact of ICT Investment on Establishment Productivity, Center for European Economic Research (ZEW), Mannheim, Germany. 
IJIKMMENA

$3,3 / 4$

\section{ABOUT THE AUTHORS}

Ms Sarvenaz Hojabr Kiani is a PhD student at the Faculty of Business, Multimedia University, Melaka, Malaysia.

Dr Elsadig Musa Ahmed is an Associate Professor and Coordinator for postgraduate programmes, and Chairperson of the Center for Globalization and Sustainability Research at the Faculty of Business, Multimedia University. He is a reviewer and an expert on the second Millennium Ecosystem Assessment report "Biodiversity and Human Well-being: A Synthesis Report for the Convention on Biological Diversity, 2005", Economic Modelling, Journal of Productivity Analysis, World Journal of Science, Technology and Sustainable Development, and Telecommunications Policy. 
